\title{
PROFIL KREATIVITAS CALON GURU FISIKA DENGAN MANAJEMEN PEMBELAJARAN BERBASIS GAYA BELAJAR
}

\author{
Wiwik Agustinaningsih \\ Program Studi Tadris Fisika, Universitas Islam Negeri Antasari Banjarmasin \\ Email: wiwikagustina@uin-antasari.ac.id
}

Diterima: 9 Januari 2020 Disetujui: 20 Maret 2020

\begin{abstract}
Abstrak
Penelitian ini bertujuan untuk menjelaskan profil kreativitas mahasiswa calon guru fisika berdasarkan perbedaan gaya belajar, yakni visual, auditori, dan kinestetik. Metodologi yang digunakan adalah pendekatan sistem dengan tahapan analisis kebutuhan sistem, mendesain sistem, dan analisis dampak sistem. Instrumen menggunakan angket analisis karakteristik gaya belajar, modul pengembangan bahan ajar yang memuat runtutan tugas pengembangan, dan lembar penilaian kreativitas produk. Sampel mahasiswa program studi Tadris Fisika semester V tahun akademik 2019/2020 yang memprogramkan mata kuliah Pengembangan Bahan Ajar Fisika. Analisis dilakukan secara deskriptif terhadap produk pengembangan bahan ajar yang diselesaikan oleh mahasiswa. Berdasarkan analisis produk pengembangan bahan ajar oleh masing-masing kelompok dideskripsikan bahwa kelompok mahasiswa visual dengan tugas mengembangkan video pembelajaran termasuk kategori sangat kreatif karena memenuhi aspek fleksibilitas dan orisinil. Kelompok mahasiswa auditori dengan pengembangan audio pembelajaran termasuk kategori kreatif dengan memenuhi aspek kelancaran dan fleksibilitas. Sedangkan kelompok kinestetik termasuk kategori kurang kreatif karena hanya memenuhi aspek kelancaran dalam penyelesaian tugas proyek.
\end{abstract}

Kata Kunci: : Kreativitas, Calon Guru Fisika, Perbedaan Individual, Gaya Belajar.

\begin{abstract}
This study aims to explain the creativity profile of prospective physics teacher students based on differences in learning styles, namely visual, auditory, and kinesthetic. The methodology used is a system approach with stages of system requirements analysis, system design, and system impact analysis. The instrument used a questionnaire analysis of learning style characteristics, teaching material development module that contained a sequence of development tasks, and a product creativity assessment sheet. The sample of Physics Education students in the fifth semester of the academic year 2019/2020 programmed Physics Teaching Materials Development courses. The analysis was conducted descriptively on the teaching material development products that were completed by students. Based on the analysis of the product development of teaching materials by each group it is described that the group of visual students with the task of developing learning videos is very creative because it meets the aspects of
\end{abstract}


flexibility and originality. Auditory student groups with the development of audio learning including creative categories by fulfilling aspects of fluency and flexibility. While the kinesthetic group is included in the less creative category because it only fulfills aspects of fluency in completing project tasks.

Keywords: Creativity, Physics Teacher Candidates, Individual Differences, Learning Styles.

\section{PENDAHULUAN}

Kreativitas merupakan sebuah tujuan pembelajaran yang jarang diperhatikan. Pentingnya kreativitas dalam pembelajaran disimpulkan dari hasil penelitian terdahulu bahwa mahasiswa dengan kreativitas tinggi memiliki kemampuan penyelesaian masalah yang tinggi (Andari \& Lusiana, 2015) dan prestasi belajar lebih baik (Hanggara, 2015).

Penelitian lainnya di kota Bandung menemukan bahwa guru sudah merencanakan pengembangan kreativitas siswa yang terlihat dalam Rencana Pelaksanaan Pembelajaran (RPP). Namun saat aplikasi di kelas, tujuan tersebut kurang diperhatikan dengan berbagai alasan. Terlebih lagi ada temuan bahwa guru yang tersertifikasi lebih memperhatikan pengembangan kreativitas dibandingkan guru yang belum tersertifikasi (Fauziah, 2011).
Duff menyatakan bentuk kecerdasan kreatif adalah kemampuan bawaan seseorang untuk menggabungkan dan mengevaluasi ide-ide dengan kualitas estetika dalam membentuk ide baru. Prosesnya melibatkan imajinasi asosiatif (Korotkova, 2018).

Kreatif dimaksudkan pada perbedaan cara menyelesaikan masalah secara cepat, fleksibel, dan baru yang unik. Berdasarkan beberapa pendapat menyebutkan kreativitas adalah sumber perkembangan masyarakat yang progresif (Korotkova, 2018); bergantung pada pengetahuan, kecerdasan umum, dan kecerdasan emosi (Şahin, 2016); kreasi kebutuhan baru sebagai akibat transisi dari masa sebelumnya (Eisler, Donnelly, \& Montuori, 2016); inisiatif individu terhadap suatu produk atau proses agar lebih bernilai (Hadiyati, 2011).

Berdasarkan pendapat tersebut maka kreativitas penting digali untuk 
Agustinaningsih. - Profil Kreativitas Calon Guru ...

kemudian dikembangkan dalam pengalaman inderanya menerima proses pendidikan seseorang. informasi. Gaya belajar terbagi Khususnya untuk para calon guru menjadi visual, auditori, dan fisika, proses tersebut dapat melalui manajemen pembelajaran yang sesuai kinestetik.

Visual dengan kekuatan informasi dengan karakteristik mahasiswa.

Mahasiswa sebagai subjek belajar memiliki karakteristik tersendiri seperti gaya belajar. Gaya belajar adalah cara yang mudah dan cepat bagi seseorang untuk menyerap informasi dengan mengoptimalkan fungsi inderanya baik pendengaran, penglihatan, maupun peraba. Dengan memperhatikan karakteristik yang sudah dimiliki masing-masing individu maka diharapkan dapat memudahkan pengajar maupun mahasiswa dalam proses pembelajaran itu sendiri.

Terkait pengajar, mahasiswa, gaya mengajar, dan gaya belajar terdapat permasalahan khusus, dimana hasil penelitian terdahulu $70 \%$ gaya belajar mahasiswa tidak bersesuaian dengan gaya mengajar dosen sehingga berdampak pada kurang efektifnya hasil belajar pada mahasiswa (Papilaya \& Huliselan, 2016).

Gaya belajar merupakan salah satu karakteristik unik setiap orang dalam pada pengalaman indera untuk melihat secara langsung. Pengalaman auditori dengan mendengarkan informasi secara seksama. Kinestetik dengan cara bekerja dan melakukan sendiri kegiatan yang menariknya untuk memperoleh pengetahuan.

Gaya belajar menjadi fokus dalam penelitian ini karena berhubungan langsung dengan kreativitas. Pengalaman estetika siswa mempengaruhi kreativitas dan keyakinan diri siswa terhadap potensi kreatifnya (Chang, Yuan-Cheng \& Hsiao, 2016). Estetika berhubungan dengan keindahan baik dalam pengamatan produk seni maupun alam semesta yang diserap melalui pancaindera manusia. Pancaindera dalam proses pembelajaran umumnya ialah pendengaran, penglihatan, dan peraba.

Berdasarkan hal ini ada hubungan yang kuat antara pengalaman indera (penglihatan, pendengaran, dan peraba) dengan estetika (aesthetics 
Agustinaningsih. - Profil Kreativitas Calon Guru ...

experience). Lebih lanjut, estetika berhubungan dengan kreativitas individu.

Semiawan (2007) menyebutkan bahwa untuk menguasai ilmu pengetahuan tidak harus diperoleh individu dengan cara yang sama. Perbedaan cara akan meminimalisir faktor tekanan bagi pendidik. Pencapaian mahasiswa pada hasil belajarnya dapat diupayakan dengan maksimal melalui proses pembelajaran yang sesuai dengan gaya belajarnya.

Informasi umumnya disampaikan melalui media suara, gambar/digital, maupun kerja mekanis. Media suara sebagai bagian dari auditori, gambar/digital sebagai sarana visual, dan kerja mekanis menunjukkan pada sistem kerja kinestetik. Perkuliahan yang berbasis media dapat menguatkan pengalaman pembelajaran individu (Huang et al., 2012)

Mahasiswa Tadris Fisika UIN Antasari Banjarmasin semester V memprogramkan mata kuliah Pengembangan Bahan Ajar Fisika tahun akademik 2019/2020. Hal ini memungkinkan proses pengembangan produk media kreatif yang memperhatikan kesesuaian gaya belajar mahasiswa.

Dalam penelitian terdahulu, Agustinaningsih (2018) menemukan bahwa ketuntasan kelas dengan penyesuaian gaya belajar pada proses pembelajaran adalah sebesar $70 \%$. Namun kelemahan dalam hasil penelitian adalah kurangnya waktu khusus untuk mengkaji hasil pekerjaan siswa. Untuk itu perlu adanya pendekatan sistem yang berkembang.

Keberhasilan perkuliahan bergantung pada pengawasan sistem yang memperhatikan perbedaan individual. Untuk meningkatkan kreativitas siswa, universitas harus menekankan pada pengembangan pengalaman estetika dan evaluasi pendekatan pengajaran kreativitas (Chang, Yuan-Cheng \& Hsiao, 2016).

Analisis kebutuhan sistem, desain sistem, dan evaluasi dampak sistem menjadi tahapan yang dilaksanakan dalam penelitian ini. Tujuannya agar diperoleh profil kreativitas yang mendeskripsikan daya kreativitas mahasiswa secara lengkap berdasarkan gaya belajar. 
Agustinaningsih. - Profil Kreativitas Calon Guru ...

\section{METODE}

Penelitian dilakukan dengan menggunakan pendekatan sistem. Semiawan (2007) menyebutkan bahwa pendekatan sistem diperlukan untuk memperoleh berbagai informasi dan pengetahuan dalam mengadakan keputusan penting untuk meningkatkan kinerja organisasi. Adapun pendekatan sistem kegiatan pembelajaran pada gambar 1 .

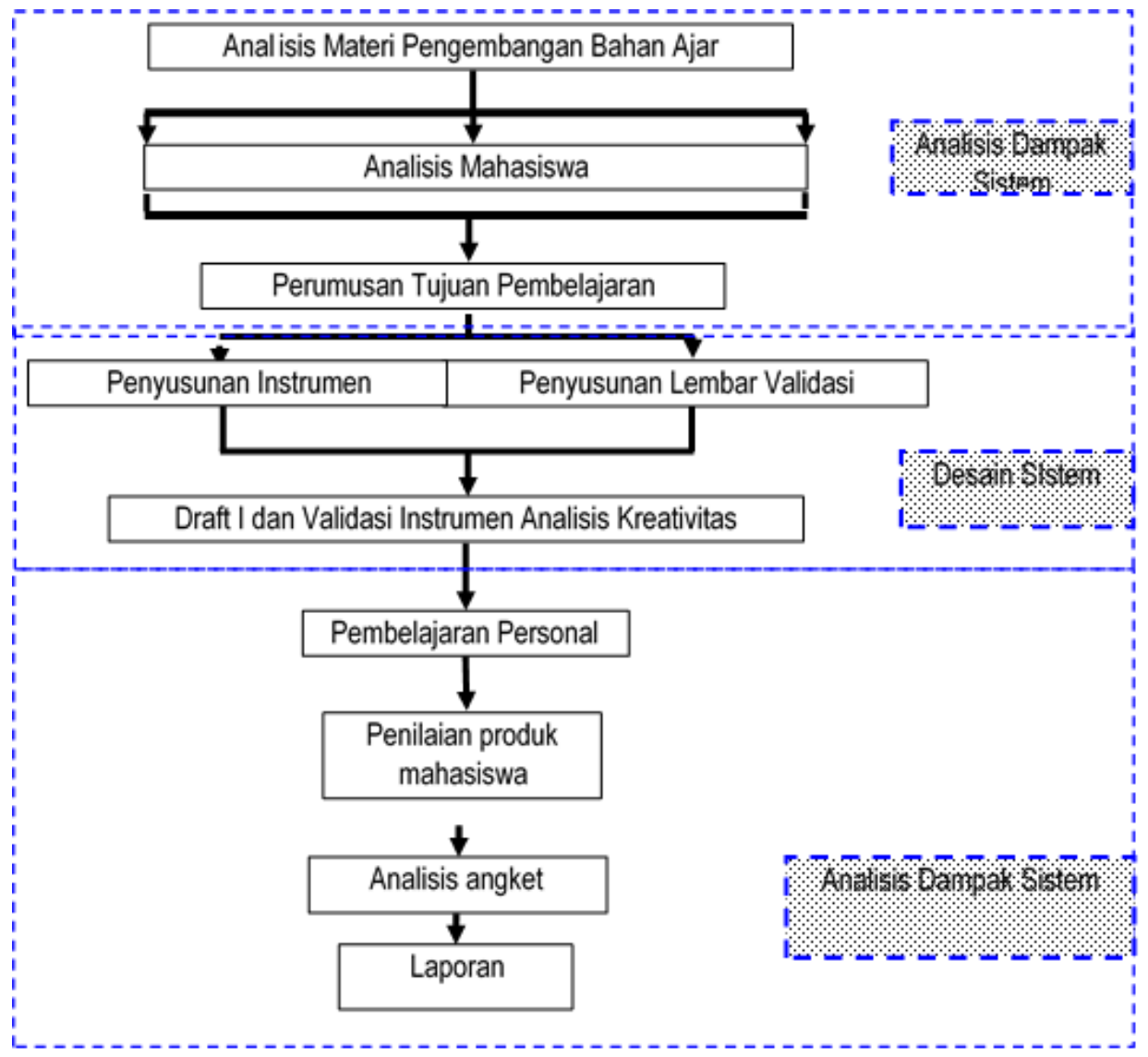

Gambar 1. Tahap Pendekatan Sistem (sumber adaptasi Susilowati, Jamal, \& Suyidno., 2012)

Penelitian ini dilakukan terhadap mahasiswa Tadris Fisika semester V yang memprogramkan mata kuliah Pengembangan Bahan Ajar Fisika tahun akademik 2019/2020. Mahasiswa sejumlah 16 orang yang memiliki sebaran gaya belajar visual 6 orang, auditori 6 orang, dan kinestetik 4 orang. Hasil sebaran ini diperoleh dengan analisis angket gaya belajar yang diberikan pada 
mahasiswa saat awal kegiatan perkuliahan.

Analisis data dilakukan sesuai tahapan pendekatan sistem yakni pada deskripsi gaya belajar mahasiswa calon guru fisika dengan persentase, Pada desain sistem dengan memilih desain pembelajaran yang mendukung proses perkuliahan berbasis gaya belajar, dan analisis dampak sistem dengan penilaian kreativitas produk menurut kriteria aspek kreativitas pada lembar penilaian.

Kriteria penilaian produk kreatif dalam 5 skala (sangat kreatif sampai dengan tidak kreatif) menurut aspek kreativitas yang dipenuhi, yakni kelancaran, kelenturan, elaborasi, dan kebaruan seperti pada tabel 1 . Penilaian dilakukan pada produk akhir kelompok mahasiswa sesuai gaya belajarnya.

Kelompok visual mengembangan bahan ajar berupa video pembelajaran. Kelompok auditori mengembang audio pembelajaran, dan kelompok kinestetik merancang pengembangan modul praktikum yang terintegrasi alat peraga fisika sederhana.

Tabel 1. Kriteria Penilaian Kreativitas Pengembangan Bahan Ajar Mahasiswa

\begin{tabular}{c|l}
\hline Kriteria Penilaian & \multicolumn{1}{c}{ Keterangan } \\
\hline Sangat kreatif & $\begin{array}{l}\text { Tugas proyek menunjukkan kelancaran, fleksibilitas, dan } \\
\text { kebaruan, atau kebaruan dan fleksibilitas }\end{array}$ \\
\hline Kreatif & $\begin{array}{l}\text { Tugas proyek menunjukkan kelancaran dan kebaruan, atau } \\
\text { kelancaran dan fleksibilitas }\end{array}$ \\
\hline Cukup Kreatif & $\begin{array}{l}\text { Tugas proyek menunjukkan salah satu aspek, kebaruan saja } \\
\text { atau fleksibilitas saja }\end{array}$ \\
\hline Kurang Kreatif & Tugas proyek menunjukkan kelancaran \\
\hline Tidak Kreatif & Tugas proyek tidak menunjukkan aspek kreativitas \\
\hline
\end{tabular}

Sumber: Adaptasi (Richardo, Mardiyana, \& Saputro, 2014)

\section{HASIL DAN PEMBAHASAN}

\section{Analisis Kebutuhan Sistem}

Mahasiswa yang memprogramkan mata kuliah pengembangan bahan ajar sebanyak 16 orang mahasiswa.
Pada tahap awal, jenis gaya belajar mahasiswa diketahui melalui angket identifikasi gaya belajar (De Potter, 2007) dengan persentase Visual dan Auditorial masing-masing 35,29\% 
Agustinaningsih. - Profil Kreativitas Calon Guru ...

dan Kinestetik 29,42\%. Pemetaan gaya belajar seluruh mahasiswa yang menjadi tahapan penemuan pada pembelajaran personal.

Persentase visual dan auditori lebih besar daripada kinestetik. Hal ini ditemukan pula dalam hasil penelitian oleh Johnson dan Miller bahwa mahasiswa yang belajar disiplin ilmu fisika, matematika, dan kimia, lebih cenderung untuk memiliki gaya belajar visual (Papilaya \& Huliselan, 2016). Gaya belajar visual cenderung pada kekuatan indera penglihatan.

\section{Mendesain Sistem}

Tahap desain sistem dilakukan dengan penyusunan draf I instrumen pendukung analisis meliputi modul pengembangan bahan ajar dengan lembar proyek mahasiswa didalamnya, dan lembar penilaian kreativitas yang mengacu pada indikator tabel 1. Selanjutnya instrumen hasil rancangan ditelaah oleh validator dari pakar pendidikan fisika dan kreativitas.

Modul pengembangan bahan ajar berisi tahapan pembelajaran personal sebagai pengalaman belajar bagi mahasiswa. Modul berfungsi sebagai instruksi tahapan pembelajaran.
Instruksi untuk meningkatkan motivasi kreatif siswa secara positif mempengaruhi pengalaman estetika siswa (Chang, Yuan-Cheng \& Hsiao, 2016). Isi bagian pertama modul terkait kreativitas siswa.

Karakteristik siswa merupakan faktor pembawaan yang menjadi modal belajar bagi siswa. Karakteristik tersebut dikenal sebagai perbedaan-perbedaan individual yang harus mendapat perhatian oleh pengajar. Sit (2012) menyebutkan lima perbedaan individual diantaranya perbedaan fisik, perbedaan intelegensi, perbedaan gaya belajar dan gaya berpikir, perbedaan kepribadian, dan perbedaan tempramen. Pengenalan terhadap gaya belajar siswa ada pada awal proses desain pembelajaran.

Bentuk desain pembelajaran personal dalam penelitian ini direduksi dari Personalized System of Instruction (PSI) oleh Fred S. Keller dan Pelatihan Individual. Kelemahan pada kedua sistem tersebut dipandang dari segi manajemen waktu dan kelas. PSI memberi perhatian yang khusus kepada setiap pelajar untuk menguasai objek belajar sesuai 
dengan kecepatannya masing-masing. Artinya siswa diberi kesempatan untuk belajar tanpa batasan waktu dan tidak dibatasi oleh periode kelas serta peraturan akademik yang diberlakukan oleh sekolah (Ginanjar, 2019).

Permasalahan waktu dan psikologis menjadi pertimbangan bagi pengajar. Hasil penelitian tentang tekanan kejiwaan dan waktu menemukan hubungan positif antara manajemen waktu dan tingkat stres pada proses pembelajaran (Besong, 2015).

Sedangkan pada pelatihan individual disebutkan bahwa seluruh siswa mendapatkan pengalaman yang sama, tetapi menyelesaikan pembelajaran dengan waktu yang berbeda sesuai kemampuannya. Padahal dengan perbedaan pengalaman belajar apalagi bersesuaian dengan gaya belajar mahasiswa, maka dapat menjadi motivasi sekaligus menggali kreativitasnya dalam belajar.

Empat tahapan pembelajaran personal untuk mengetahui profil kreativitas yakni Penemuan, Desain Tugas (dengan Problem Based Learning), Pengembangan (dengan Creative Problem Solving), dan Pemantauan seperti pada gambar 2.

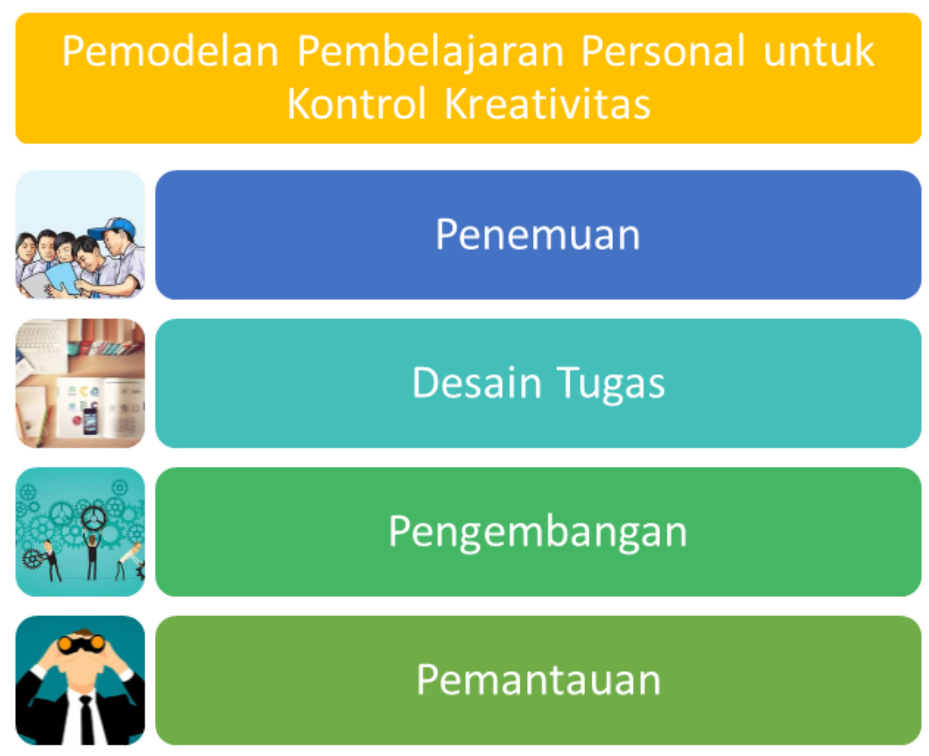

Gambar 2. Pembelajaran Personal 
Penemuan. Pembelajaran ini Materi. Selanjutnya mahasiswa menekankan tahapan mengenal individual mahasiswa. Kreativitas berhubungan dengan pengalaman indera, dalam hal ini gaya belajar. Untuk itu pengajar memberikan angket identifikasi karakteristik gaya belajar pada mahasiswa. Hasilnya didapatkan sebaran gaya belajar yang ada pada perkuliahan pengembangan bahan ajar. Yakni visual 6 orang, auditori 6 orang, dan kinestetik 4 orang mahasiswa.

Desain Tugas. Tahapan ini menggunakan Pembelajaran Berbasis Proyek atau Project Based Learning (PBL) dalam pelaksanaannya. PBL adalah model pembelajaran yang melibatkan siswa dalam suatu kegiatan (proyek) yang menghasilkan suatu produk. Keterlibatan siswa mulai dari merencanakan, membuat rancangan, melaksanakan, dan melaporkan hasil kegiatan berupa produk dan laporan pelaksanaanya.

Pada tahapan ini mahasiswa yang sudah terbagi dalam 3 kelompok sesuai dengan gaya belajarnya mengkaji materi pada bahan ajar. Sub tema yang ditelaah adalah Karakteristik Siswa dan Karakteristik melakukan kajian ke sekolah untuk menganalisis karakteristik siswa (dengan angket gaya belajar) dan mengetahui materi yang akan dibelajarkan selanjutnya (telaah kurikulum).

Pengembangan. Pada tahapan ini pengajar menyiapkan 3 media belajar visual (video pembelajaran), auditori (audio pembelajaran), dan kinestetik (Modul petunjuk praktikum). Mahasiswa mempelajari bersama kelompoknya jenis bahan ajar yang sesuai dengan jenis gaya belajarnya. Contohnya kelompok mahasiswa dengan gaya belajar visual mengkaji video pembelajaran, kelompok auditori mengkaji audio pembelajaran, dan kelompok kinestetik menelaah modul praktikum.

Hasil kegiatan ini berupa analisis media pembelajaran termasuk kekurangan dan kelebihannya. Hasil tersebut digunakan untuk pengembangan bahan ajar oleh mahasiswa pada materi yang akan dibelajarkan di kelas yang sudah diobservasi sebelumnya. 
Pemantauan. Tahap pemantauan dinilai dengan proses pengembangan bahan ajar yang dilakukan kelompok mahasiswa hingga menghasilkan produk draft I bahan ajar berupa video pembelajaran, audio pembelajaran, dan modul praktikum. Pada tahapan ini pula diberikan angket untuk memantau daya kreativitas mahasiswa.

\section{Analisis Dampak Sistem}

Analisis data menggunakan analisis deskriptif kualitatif melalui klasifikasi hasil produk pengembangan bahan ajar kelompok mahasiswa. Produk yang dikembangkan masing-masing kelompok yakni video pembelajaran (visual), audio pembelajaran (auditori), dan modul praktikum (kinestetik). Semuanya dikategorikan berdasar kriteria penilaian.

Kriteria penilaian produk kreatif dalam 5 skala menurut aspek kreativitas yang dipenuhi, yakni kelancaran, kelenturan, elaborasi, dan kebaruan seperti pada tabel 2.

Tabel 2. Telaah Produk Bahan Ajar Buatan Mahasiswa

\begin{tabular}{c|l|l|l}
\hline $\begin{array}{c}\text { Gaya belajar dan } \\
\text { Produk }\end{array}$ & $\begin{array}{c}\text { Kinestetik (Pembuatan } \\
\text { modul praktikum) }\end{array}$ & $\begin{array}{c}\text { Visual (pembuatan } \\
\text { video pembelajaran) }\end{array}$ & $\begin{array}{c}\text { Auditori (pembuatan } \\
\text { audio pembelajaran) }\end{array}$ \\
\hline \multirow{5}{*}{$\begin{array}{c}\text { Deskripsi hasil } \\
\text { tugas }\end{array}$} & $\begin{array}{l}\text { Proyek selesai sampai } \\
\text { dengan daftar pustaka } \\
\text { (kelancaran) }\end{array}$ & $\begin{array}{l}\text { Belum selesai sampai } \\
\text { penjelasan materi dan } \\
\text { kesimpulan (tidak } \\
\text { menunjukkan } \\
\text { kelancaran) }\end{array}$ & $\begin{array}{l}\text { Rekaman audio sampai } \\
\text { selesai (kelancaran) }\end{array}$ \\
\cline { 2 - 4 } & $\begin{array}{l}\text { Layout tidak berbeda dari } \\
\text { contoh (tidak } \\
\text { menunjukkan } \\
\text { Fleksibilitas) }\end{array}$ & $\begin{array}{l}\text { Urutan visualisasi } \\
\text { materi berbeda dengan } \\
\text { contoh (fleksibilitas) }\end{array}$ & $\begin{array}{l}\text { Teknik penyampaian } \\
\text { materi berbeda dari } \\
\text { contoh (Fleksibilitas) }\end{array}$ \\
\cline { 2 - 5 } & $\begin{array}{l}\text { Isi materi sama dengan } \\
\text { modul percobaan/tidak } \\
\text { ada pengembangan } \\
\text { materi (tidak } \\
\text { menunjukkan elaborasi) }\end{array}$ & $\begin{array}{l}\text { Menambah video lain } \\
\text { yang relevan } \\
\text { (elaborasi) }\end{array}$ & $\begin{array}{l}\text { Tidak memuat musik } \\
\text { yang mempengaruhi } \\
\text { suasana psikologis } \\
\text { belajar (tidak ada } \\
\text { elaborasi) }\end{array}$ \\
\cline { 2 - 5 } & $\begin{array}{l}\text { Belum menunjukkan } \\
\text { kebaruan (tidak orisinil) }\end{array}$ & $\begin{array}{l}\text { Scene pengantar awal } \\
\text { video memuat nama } \\
\text { anggota kelompok } \\
\text { visual yang unik } \\
\text { (orisinil) }\end{array}$ & $\begin{array}{l}\text { Belum menunjukkan } \\
\text { kebaruan (tidak } \\
\text { orisinil) }\end{array}$ \\
\hline
\end{tabular}


Berdasarkan acuan tabel 1 3. Hasil tes kemampuan berpikir terhadap klasifikasi kreativitas, maka kreatif matematik siswa pada tabel 3 kelompok mahasiswa visual termasuk menunjukkan skor tertinggi diperoleh kategori sangat kreatif karena 3 orang siswa atau sekitar 10,3\% dari memenuhi aspek fleksibilitas, jumlah siswa yang mengikuti tes. elaborasi, dan orisinil. Kelompok Perolehan ini dengan kategori sangat mahasiswa auditori termasuk kategori baik. Siswa yang tergolong sangat kreatif dengan memenuhi aspek baik dalam kemampuan berpikir kelancaran dan fleksibilitas. kreatif memiliki 3 aspek kreativitas Sedangkan kelompok kinestetik utama (Islami, Putri, \& Nurdwiandari, termasuk kategori kurang kreatif 2018). Aspek tersebut yakni karena hanya memenuhi aspek menghasilkan banyak ide (fluency), kelancaran dalam penyelesaian tugas variasi ide (flexibility), dan ide baru proyek. (originality).

Hasil penelitian terkait capaian aspek kreativitas disajikan pada tabel

Tabel 3. Perolehan skor kemampuan berpikir kreatif matematik siswa

\begin{tabular}{ccc}
\hline Skor & Banyak Siswa & Keterangan \\
\hline 12 & 3 & Sangat Baik \\
9 & 15 & Baik \\
6 & 11 & Cukup Baik \\
3 & 0 & Tidak Baik \\
0 & 0 & Sangat Tidak Baik \\
\hline Jumlah 29 & &
\end{tabular}

Sumber: (Islami et al., 2018)

Analisis terhadap kelompok dikategorikan kurang kreatif. Sebagai mahasiswa auditori sejalan dengan hasil penelitian (Richardo et al., 2014) temuan, kedua hasil tersebut bahwa siswa dengan gaya belajar mengarah pada pembelajar kinestetik visual dan auditori termasuk dalam yang menunjukkan analisis yang pembelajar kreatif sedangkan siswa sama.

Ciri siswa dengan gaya belajar dengan gaya belajar kinestetik kinestetik diantaranya sulit untuk 
Agustinaningsih. - Profil Kreativitas Calon Guru ...

bediam diri dalam waktu lama, ingin melakukan segala sesuatu, juga kurang mampu menulis dengan rapi (Sit, 2012). Sementara dalam tugas proyek yang dilakukan, kelompok mahasiswa kinestetik diberikan tugas pengembangan modul praktikum.

Sekalipun berkaitan dengan tugas melibatkan fisik, namun proses menulis modul dapat menjenuhkan bagi kelompok ini karena kurangnya kemampuan dalam menulis rapi. Dengan keinginan untuk melakukan segala sesuatu, maka tugas yang harus ditekuni lama akan memacu mereka untuk bekerja cepat (kelancaran) tanpa memperhatikan unsur lain yang memperkaya nilai tugas (kreativitas).

\section{KESIMPULAN DAN SARAN}

\section{Kesimpulan}

Mahasiswa tadris fisika semester V tahun akademik 2019/2020 terbagi menjadi 3 kategori gaya belajar. Analisis memberikan profil sebaran gaya belajar visual 35,29\% (6 orang), auditori $35,29 \%$ (6 orang), dan kinestetik 29,41\% (4 orang).

Bentuk pemodelan pembelajaran personal untuk kontrol kreativitas dengan 4 tahapannya yakni penemuan, desain tugas, pengembangan, dan pemantauan. Pemodelan ini sebagai bentuk manajemen perkuliahan berbasis gaya belajar untuk tujuan mengetahui profil kreativitas mahasiswa calon guru fisika.

Hasil analisis produk mahasiswa diperoleh profil kreativitas dalam pengembangan bahan ajar yakni visual termasuk kategori sangat kreatif karena memenuhi aspek fleksibilitas dan orisinil. Kelompok mahasiswa auditori termasuk kategori kreatif dengan memenuhi aspek kelancaran dan fleksibilitas. Sedangkan kelompok kinestetik termasuk kategori kurang kreatif karena hanya memenuhi aspek kelancaran dalam penyelesaian tugas proyek.

\section{Saran}

Angket identifikasi gaya belajar dapat menggunakan angket identifikasi yang tersedia online atau mengolah instrumen angket yang sudah baku ke dalam bentuk online, misalnya google forms untuk memudahkan analisis sebaran gaya belajar mahasiswa. 
Agustinaningsih. - Profil Kreativitas Calon Guru ...

\section{DAFTAR PUSTAKA}

Agustinaningsih, W. (2018). Model Desain ASSURE dalam

Perangkat Pembelajaran Fisika (Pendekatan Sistem Pembelajaran yang Memperhatikan Karakteristik Gaya Belajar Siswa). Banjarmasin: Antasari Press.

Andari, T., \& Lusiana, R. (2015). Profil kreativitas mahasiswa dalam memecahkan masalah geometri pada materi sistem koordinat ruang. Jurnal Ilmiah Pendidikan Matematika, 3(2), 439-451.

Besong, J. B. (2015). Stress and Time Management Settings in University of Maroua, Cameroon. Expert Journal of Business and Management, 3(2), 105-110.

Chang, Yuan-Cheng \& Hsiao, C.-C. (2016). Students' Aesthetics Experience, Creative SelfEfficacy and Creativity: Is Creativity Instruction Effective? 65-104.

De Potter, B. (2007). Quantum Teaching: Orchestrating Student Success (terjemahan Ary Nilandari). Bandung: Kaifa

Eisler, R., Donnelly, G., \& Montuori, A. (2016). Creativity, Society, and Gender: Contextualizing and Redefining Creativity. Interdisciplinary Journal of Partnership Studies, 3(2), 0-33. https://doi.org/10.24926/ijps.v3i 2.130

Fauziah, Y. N. (2011). Analisis Kemampuan Guru dalam Mengembangkan Keterampilan berpikir Kreatif Siswa SD kelas V pada Pembelajaran IPA (Studi Komparatif pada Guru SD Kelas
V di Beberapa SD di Kota Bandung Tahun Ajaran 20102011). Metodik Didaktik (Jurnal Pendidikan Ke-SD-an, Edisi Khusus No. 2, Agustus 2011, (2), 98-106.

Ginanjar, A. (2019). The Effects of Personalized System for Instruction Learning Model on Vocational School Students' Motivation. Jurnal Pendidikan Jasmani Dan Olahraga, 4(1), 32-36.

https://doi.org/10.17509/jpjo.v4i 1.13218 .

Hadiyati, E. (2011). Kreativitas dan Inovasi Berpengaruh Terhadap Kewirausahaan Usaha Kecil. Jurnal Manajemen Dan Kewirausahaan, 13(1), 8-16.

Hanggara, Y. (2015). Eksperimentasi Model Pembelajaran Problem Based Learning Dan Inkuiri Terbimbing Pada Materi Pokok Bangun Ruang Sisi Datar Ditinjau Dari Kreativitas Siswa Smp Negeri Se-Kabupaten Blora. Pythagoras:Jurnal Program Studi Pendidikan Matematika, 1(c), 29-32. https://doi.org/10.1017/CBO978 1107415324.004

Huang, Y. M., Liang, T. H., Su, Y. N., \& Chen, N. S. (2012). Empowering personalized learning with an interactive ebook learning system for elementary school students. Educational Technology Research and Development, 60(4), 703-722. https://link.springer.com/articl e/10.1007/s11423-012-9237-6 . (diakses 23 September 2018) Islami, F. N., Putri, G. M. D., \& Nurdwiandari, P. (2018). 
Agustinaningsih. - Profil Kreativitas Calon Guru ...

Kemampuan Fluency,

Flexibility, Originality. Jurnal

Pembelajaran Matematika

Inovatif, 1(3), 249-258. https://doi.org/10.22460/jpmi.v1i 3.249-258.

Korotkova, L. V. (2018). Key Concepts of Creativity: from Antiquity to Present. Advanced Linguistics, 2, 38-42.

Papilaya, J. O., \& Huliselan, N. (2016). Identifikasi Gaya Belajar Mahasiswa. Jurnal Psikologi Undip, $\quad$ 15(1), 56. https://doi.org/10.14710/jpu.15.1 .56-63.

Richardo, R., Mardiyana, \& Saputro, D. R. S. (2014). Tingkat Kreativitas Siswa dalam Memecahkan Masalah Matematika Divergen Ditinjau dari Gaya Belajar Siswa. Jurnal Elektronik Pembelajaran Matematika, 2(2), 141-151.

Şahin, F. (2016). General intelligence, emotional intelligence and academic knowledge as predictors of creativity domains: A study of gifted students. Cogent Education, 3(1), 1-16. https://doi.org/10.1080/2331186 X.2016.1218315

Semiawan, Conny R. (2007). Catatan Kecil Tentang Penelitian dan Pengembangan Ilmu Pengetahuan. Jakarta: Kencana

Sit, M. (2012). Perkembangan peserta didik (1st ed.). Medan: Perdana Publishing.

Susilowati, Eko, Muh Arifuddin Jamal dan Suyidno. (2012). Pengembangan Modul Perkuliahan Strategi Belajar Mengajar (SBM) untuk Meningkatkan Kreativitas Mahasiswa Prodi Pendidikan Fisika FKIP Universitas Lambung Mangkurat. Laporan Penelitian, tidak diterbitkan, Universitas Lambung Mangkurat, Banjarmasin. 